\title{
Theo van Baaren's Systematic Science of Religion Revisited
}

The Current Crisis in Dutch Study of Religion and a Way Out

Markus Altena Davidsen

NTT 74 (3): 213-241

DOI: $10.5117 /$ NTT2020.3.002.ALTE

\begin{abstract}
This article revisits Theo van Baaren's (1912-1989) call for a 'systematic science of religion'. With this call Van Baaren urged Dutch scholars of religion to do away with the religionist biases of the phenomenology of religion, while retaining comparison as a cornerstone of the discipline. Unfortunately, Van Baaren's programme was never realized in the Netherlands, and Dutch study of religion became dominated instead by a particularist paradigm that, while producing eminent studies of individual religions, lacked an interest in theorizing religion in general. Deprived of a common object and aim, Dutch scholarship on religion has become fragmented, and Dutch scholars of religion have been in no good position to fend for themselves in face of institutional restructurings, budget cuts, and general hostility towards the humanities. With an eye to the Nordic countries I propose a reorientation towards a systematic science of religion à la Van Baaren as a way out of the academic and institutional crisis.
\end{abstract}

Keywords: study of religion, science of religion, Theo van Baaren, research history, the Netherlands, method and theory

All expositions of the history of the study of religion in the Netherlands after the Second World War single out Theo van Baaren (1912-1989) as the pivotal figure and identify his call for a 'systematic science of religion' as 
the key methodological turning point. ${ }^{1}$ Van Baaren's chroniclers praise him for having emancipated the study of religion (godsdienstwetenschap; religiewetenschap) from theology, and for substituting the intuitive, verstehende method of Gerardus van der Leeuw (189o-1950) with an empirical method inspired by American cultural anthropology. But Van Baaren wanted more than just to collect better historical and ethnographical facts. He wanted to develop the study of religion into a 'systematic science of religion' aimed at comparing, classifying, and explaining religious phenomena. Historians, anthropologists, sociologists, and psychologists of religion should all continue to work on their various specializations, but Van Baaren wanted them, in addition to this, to be united in the common, comparative, and 'systematic' project of understanding and explaining religion in general. Unfortunately, Van Baaren and his associates were unable to put their methodological programme for a systematic science of religion into practice. This task is still left for us to accomplish, and our discipline can win in coherence and importance if we succeed. ${ }^{2}$

The argument of the present article will proceed as follows. I begin by situating Van Baaren within the history of Dutch study of religion and present the main tenets of his programme for a 'systematic science of religion'. I then show that a systematic science of religion never became discipline-defining in the Netherlands, but that Dutch study of religion after taking leave of the phenomenology of religion became dominated instead by a particularistic paradigm which, while producing eminent studies of individual religions, remained indifferent to comparison and explanation. A main reason for this development was that Van Baaren himself, as well as

1 J.G. Platvoet, 'From Consonance to Autonomy: The Science of Religion in The Netherlands 1948-1995, Method \& Theory in the Study of Religion 10 (1998), 334-351, 335; W. Hofstee, 'Religion and Ideology: Dutch Science of Religion during the Cold War', in I. Doležalová, L.H. Martin, D. Papoušek (ed.), The Academic Study of Religion during the Cold War, New York 2001, 239-252, 247; J.G. Platvoet in M.A. Davidsen, “There Was No Dutch School of Phenomenology of Religion" - The Netherlands', in S. Fujiwara, D. Thurfjell, S. Engler (ed.), Global Phenomenologies of Religion: An Oral History in Interviews (The Study of Religion in a Global Context Series), Sheffield forthcoming.

2 A note on terminology may be needed immediately. Van Baaren and many other (older) Dutch scholars translated the Dutch term godsdienstwetenschap into 'science of religion' in English, being seemingly unaware that the English term science has a more narrow meaning (of natural science) than the Dutch term wetenschap (which has a meaning range equivalent to the German Wissenschaft). Whenever Van Baaren writes 'science of religion', one should therefore simply read 'study of religion'. In this article I will use the notion of a systematic science of religion only to refer to Van Baaren's proposed research programme; the academic discipline specialized in religion will be referred to as the Study of Religion. 
his closest associates and students, failed to realize their own methodological programme. To show that this failure was not inevitable, I turn to the Nordic countries where the study of religion was successfully developed into a secular, comparative, and theoretical discipline in the 197os through 1990s. Arguing that the particularism that dominates Dutch scholarship on religion has made our discipline vulnerable to institutional restructurings and unable to argue for its own relevance, I suggest a way out of the crisis. On the academic level, I propose a reorientation towards a systematic science of religion à la Van Baaren. We need to commit to religion as our shared object of study and hence to a shared disciplinary identity as scholars of religion; retain the ambition to compare; seek to explain the patterns we find; and base our explanations on the principle of methodological naturalism. These principles should not only guide our research, but be integrated into our teaching as well, especially the research training provided through the Netherlands School for Advanced Studies in Theology and Religion (NOSTER). Institutionally, we have much to gain by entering into a strategic partnership with secondary education. If we opt to educate school teachers who can teach the school subject Religion and Worldview (godsdienst/levensbeschouwing) in a more study-of-religion inspired way, we not only create a clear job perspective for our students but also increase the likelihood that secondary school graduates will enrol in our study programmes. Institutional support can be provided by the Dutch Association for the Study of Religion (NGG) and the NTT Journal for Theology and the Study of Religion.

\section{Theo van Baaren's call for a 'Systematic Science of Religion'}

According to Jan Platvoet, the history of the Dutch study of religion can be divided into two very distinct phases: a phenomenological phase before Van Baaren and a culturalist phase after Van Baaren. ${ }^{3}$ The phenomenological phase began with the appointment of C.P. Tiele (1830-1902) as the first Dutch Professor of History of Religion in Leiden in 1877 and ended roughly one hundred years later, in 1973, with the publication of Religion, Culture and Methodology by the Groningen Working-Group for the Study

3 Platvoet in Davidsen, "There Was No Dutch School"; see also Platvoet, 'From Consonance to Autonomy' and Hofstee, 'Religion and Ideology'. 
of Fundamental Problems and Methods of Science of Religion led by Theo van Baaren. ${ }^{4}$

During the phenomenological phase, all professors commissioned to teach history of religion within the faculties of theology at the four Dutch public universities of Leiden, Groningen, Utrecht, and Amsterdam operated within a religionist and theological paradigm characterized by three main tenets. First, religion was considered to be essentially different from all other aspects of human culture and conduct, and hence as something that could and should be studied as sui generis. Second, it was held to be self-evidently true that God exists, and that Christianity is the truest religion. In other words, the phenomenologists adhered to the principle of methodological supernaturalism, at least as far as their own religion was concerned. Third, the study of religion was considered to have two principal tasks: the historical-philological study of individual religions and the comparative study of religious phenomena across traditions. The three tenets reflected both the personal convictions of the professors during the phenomenological phase and the fact that they earned their bread by educating future ministers for the Dutch Reformed Church within the duplex ordo system.

Van Baaren dismantled the old paradigm through a series of methodological attacks on Van der Leeuw, ${ }^{5}$ and went on to formulate a programme for a new 'systematic science of religion' inspired by American cultural anthropology. Van Baaren first presented his ideas in the NTT article 'Systematische Religionswissenschaft' and later laid out his programme in more detail in his own contribution to Religion, Culture and Methodology. ${ }^{6}$ The aim of Van Baaren's systematic science of religion was to salvage the strong and useful aspects of phenomenology - in particular the paradigm's comparativism and academic self-confidence - while abandoning those aspects that were considered outdated and scientifically untenable - such as its essentialism, religionism, and Protestant bias.

4 Th.P. van Baaren, H.J.W. Drijvers (ed.), Religion, Culture and Methodology: Papers of the Groningen Working-Group for the Study of Fundamental Problems and Methods of Science of Religion, The Hague 1973.

5 In particular Th.P. van Baaren, 'De ethnologische basis van de faenomenologie van G. van der Leeuw,' Nederlands Theologisch Tijdschrift 11 (1957), 321-353.

6 Th.P. van Baaren, 'Systematische Religionswissenschaft', Nederlands Theologisch Tijdschrift 24 (1969), 81-88; 'Science of Religion as a Systematic Discipline: Some Introductory Remarks', in Van Baaren, Drijvers (ed.), Religion, Culture and Methodology, 35-56. 
Like the phenomenological paradigm Van Baaren's systematic science of religion was characterized by three tenets. First, Van Baaren viewed religion as a part of human culture and therefore as something that should not be studied in isolation (as sui generis), but always in relation to other aspects of culture and society, such as social order and art. ${ }^{7}$ This principle, which we may refer to as the culturalist principle, was formulated in explicit opposition to the essentialism that characterized Van der Leeuw's phenomenology of religion. Yet, for Van Baaren viewing religion as a 'function of culture', did not entail an erosion of the analytical border between religion and non-religion - far from it. After discussing the influential definitions of religion proposed by Clifford Geertz and Melford Spiro a few years earlier, Van Baaren 'circumscribed' (he was too humble to use the word 'define') religion stipulatively as

a complex of notions, which as a rule form a more or less connected system, concerning man and world and in which an important function is given to one or more beings and/or powers, more or less different from human beings, as a rule of superior quality, and which are generally referred to in explanations concerning the existence of world and mankind, and those concerning life after death when this belief exists. The belief in the existence of these beings and/or powers influences those who believe in their existence. ${ }^{8}$

Second, Van Baaren's programme dictated that religions should be studied as human postulations or projections - for as scholars of religion we may never know whether the culturally postulated superhuman beings really exist or not. This second principle, the principle of methodological agnosticism, was formulated in opposition to both theology and phenomenology of religion. 'Science of religion differs from theology, especially from dogmatic theology', writes Van Baaren, 'because it is limited to an empirical study of religions as they are, and because it does not acknowledge the authority of any religion to influence or determine the results of this research. ${ }^{9}$ On the difference between his own approach and the phenomenology of Van der Leeuw, he states:

Van der Leeuw uses th[e] term [epoché] to indicate a modest suspension of judgment. The scientific validity of theological statements is kept fully intact, it

7 Van Baaren, 'Science of Religion', 36-37.

8 Van Baaren, 'Science of Religion', 38.

9 Van Baaren, 'Science of Religion', 42. 
is only for the time being put in brackets (eingeklämmert) [namely while describing and comparing, before we get ready for the theological analysis; MAD] (...). The point of view defended here is not that theological pronouncements concerning the truth or untruth of a religion should be put between brackets for the time being, but that they should be crossed out definitively from the language of science of religion as irrelevant. ${ }^{10}$

Crucially, however, the programme propagated by Van Baaren shared its third principle, adherence to the comparative method, with the phenomenological paradigm. As two crucial tasks of the systematic science of religion, Van Baaren identified (1) comparison and classification of religions and religious categories (following the lead of Chantepie de la Saussaye), and (2) the synthetization of all knowledge collected by historians of religions into a general history of religion as such (in the tradition of Tiele). ${ }^{11}$ The crucial difference between (especially Van der Leeuw's) phenomenology of religion and his own systematic science of religion should be found in the superior empirical foundation of the latter, and in its much more careful attention to context. As Van Baaren put it, 'in phenomenology of religion it was allowed to divorce religious phenomena from their cultural milieu. This proceeding, which prohibits all understanding, has often been rightly attacked. Systematic science of religion should avoid this erroneous method as much as possible.12

Van Baaren also commented that the customary distinction between four departments in the science of religion - history of religion, sociology of religion, psychology of religion, and systematic science of religion (which is sometimes called phenomenology of religion or comparative religion) - is too imprecise. The first three of these departments, says Van Baaren, are actually mere 'approaches' to religion that employ the methods of other disciplines (history, sociology, psychology). Only 'the systematic science of religion, whatever name we give it, is a separate discipline based on all the relevant approaches of other disciplines, but not limited to those'. ${ }^{13}$ As Van Baaren goes on to state, the 'science of religion as a systematic discipline is based on the material collected by history, sociology, anthropology, psychology, etc., and tries to classify these materials systematically, to

10 Van Baaren, 'Science of Religion', 42, 48.

11 Van Baaren, 'Science of Religion', on comparison and classification 47, 53-54; on a gener-

al history of religion 44-45.

12 Van Baaren, 'Science of Religion', 50.

13 Van Baaren, 'Science of Religion', 44, emphasis added. 
understand and to explain them. ${ }^{14}$ In other words, it is only when historians, anthropologists, sociologists, and psychologists of religion unite in the common cause of understanding and explaining religion in general that the science/study of religion as a coherent and independent discipline is born - and with this the necessity of independent departments and study programmes in the study of religion.

\section{The actual state of affairs today: particularism and Religiewetenschappen}

As Platvoet tells the story, Van Baaren's paradigm became the new mainstream, and Dutch study of religion has now found itself in a culturalist Van Baaren-phase for almost 50 years. ${ }^{15}$ But is Platvoet right to say so? I am not so sure. As Platvoet himself admits, many 'give van Baaren more credit for his methodological revolution than is perhaps his due. ${ }^{16}$ My own experience of working as a scholar of religion in the Netherlands (in Leiden) for the past eleven years has taught me that Van Baaren's systematic science of religion never became mainstream in the Netherlands, and that it therefore failed to sustain a sense of shared aim and disciplinary identity for Dutch scholars of religion. The real mainstream in the Dutch study of religion became what I suggest to call the particularistic paradigm. This paradigm shares with Van Baaren's vision the view that religions should be studied as parts of culture, and that this should be done from a methodologically agnostic point of view. But it lacks the comparative and explanatory ambition of Van Baaren's systematic science of religion. Particularistic scholars of religion are content with providing descriptions, ethnographic or historical, of particular religions, periods, or persons. This is by no means an unusual state of affairs - the particularistic mode dominates the study of religion internationally - and I am not saying that there is anything wrong with particularistic scholarship. We need specialist studies and Van Baaren acknowledged that as much as anyone. I am only saying that purely specialist studies do not as such, yet, make a contribution to the study of religion as a systematic discipline. As Clifford Geertz reminds us, 'small facts speak

14 Van Baaren, 'Science of Religion', 45.

15 Platvoet in Davidsen, “There Was No Dutch School”; Platvoet, 'From Consonance to Autonomy'.

16 Platvoet, 'From Consonance to Autonomy', 339; cited in Hofstee, 'Religion and Ideology', 247 . 
to large issues (...) [only] because when they are made to' - only when they are connected to broader research problems and utilized for theory development. ${ }^{17}$

One can identify several indicators of a particularistic mentality in Dutch study of religion. Most basically, there is the lack of a shared academic identity as scholars of religion. I have noted that most of my colleagues do not see themselves primarily as 'scholars of religion', but rather identify as members of another discipline (say, as historians, psychologists, or anthropologists), or as area or tradition specialists (say, as Africanists, Buddhologists, or Islamologists). I have often heard colleagues profess that they would be just as happy to work in a section for History or Anthropology, and to express doubt whether it is necessary or beneficial to sustain independent research centres and degree programmes in the study of religion.

The lack of a shared identity as scholars of religion goes hand in hand with the widespread phenomenon of 'discipline denial'. The majority of those employed at the sections for the study of religion in the Netherlands are of the opinion that the study of religion does not constitute a discipline of its own, but, at best, a transdisciplinary 'research field'. Moreover, discipline denial is ingrained into the very terminology used to describe departments and study programmes. All Dutch BA programmes in the study of religion are called religiewetenschappen (literally 'sciences of religion'; sciences in the plural), and several departments and capacity groups are referred to be the same term. This terminology is odd, given that other humanistic study programmes and departments in the Netherlands have ordinary, singular names (philosophy, not philosophies; history, not histories). One could hope that religiewetenschappen was barely an unfortunate translation of the English term religious studies, but there is more to it than that. As Jan Platvoet pointed out to me, the umbrella term religiewetenschappen was introduced in the 198 os at the Catholic University in Nijmegen with the deliberate aim of stressing the independence of the sociology, psychology, history, anthropology, and philosophy of religion vis-à-vis the neutral, comparative study of religion which Van Baaren terms systematic science of religion, but which usually went by the term comparative study of religion (vergelijkende godsdienstwetenschap). This was done in order to insist that these sub-disciplines were subservient not to the comparative study

17 C. Geertz, The Interpretation of Cultures: Selected Essays by Clifford Geertz, New York 1973,23 . 
of religion but to such theological disciplines as practical theology (in the case of sociology and psychology of religion) and missiology (in the case of anthropology of religion). ${ }^{18}$ At the state universities of Leiden, Utrecht, Amsterdam, and Groningen, the sociology, anthropology, psychology, and history of religion remained relatively independent of theology, but even at those universities the notion of godsdienstwetenschappen and later religiewetenschappen took root. The effect, which lasts till the present day, has been that the comparative study of religion (in the singular) is not seen as that which unites us all (such as Van Baaren would have it), but as a particular approach, besides other particular approaches, that only colleagues hired explicitly to do comparative religion need to concern themselves with. In other words, at the state universities the plural religiewetenschappen served and serves to insulate the various approaches to religion from each other and stands in the way of integration and cooperation. ${ }^{19}$

A third particularism indicator - and one that I find particularly painful - is that since 1990 no book has been published by a Dutch scholar of religion that treats the general history of religion or offers a general introduction to the study of religion. One may wonder how this is possible in a country home to no less than six chairs for the comparative study of religion (in Leiden, Groningen, Utrecht, Amsterdam, Nijmegen, and Tilburg). Whatever one may think of the phenomenologists Chantepie de la Saussaye, H.W. Obbink, Van der Leeuw, Bleeker, and Waardenburg, every one of them can be credited for having written at least one general introduction to the history of religion or the study of religion. Each of these scholars also had their specializations - for example, Van der Leeuw was an Egyptologist and Jacques Waardenburg (1930-2015) was an Islamologist - but more fundamentally they considered it their task to contribute to the study of religion in general, by writing overviews of the history of religion and of the key categories and methods of the study of religion. Van Baaren kept this tradition alive for a while with his Doolhof der goden, first published in 1960 and updated in 1980, but after 1980 not a single professor of comparative religion belonging to the post-phenomenological paradigm has published a book, academic or popularizing, on the general history of

18 J.G. Platvoet, personal communication 30 December 2019.

19 The development of the plural religiewetenschappen is wholly unique to the Dutch language. In German and the Scandinavian languages in which it would be completely normal to speak of, for example, Geisteswissenschaften or humanvidenskaber in the plural, no-one would dream of speaking of Religionswissenschaften or religionsvidenskaber. 
religion or on the study of religion as such. ${ }^{20}$ The last Dutch book with such a general aim was Jacques Waardenburg's Religie onder de loep which is now 30 years old. ${ }^{21}$ Waardenburg's neo-phenomenology, with its focus on subjective meaning over objective structures, was far from the systematic science of religion that Van Baaren wanted and which I believe we need, but at least Waardenburg tried, and his attempt deserved better than the cold-shouldering it actually met. ${ }^{22}$

Finally, there is the role played by national institutions. The Dutch Association for the Study of Religion (Nederlands Genootschap voor Godsdienstwetenschap; NGG) could have taken over the function of the Groningen Working-Group as a platform for thinking through the fundamental problems of the study of religion, but the association's annual conferences have not been used to put issues of method, theory, and disciplinary identity on the agenda. Also, the Dutch Association for the Study of Religion and the Netherlands School for Advanced Studies in Theology and Religion (NOSTER), the national graduate school, have been either unwilling or unable to nurture a generalist mentality in the new generation of scholars. When during our graduate studies Egil Asprem and myself

20 Th.P. van Baaren, Doolhof der goden: Inleiding tot de vergelijkende godsdienstwetenschap, Groningen $198 \mathrm{o}^{2}$, with L. Leertouwer. Doolhof der Goden was reissued in 2002, after Van Baaren's death in 1989. For this third and final issue, Lammert Leertouwer made some minor revisions to the text, based on notes left for this purpose by Van Baaren.

21 J. Waardenburg, Religie onder de loep: Systematische inleiding in de godsdienstwetenschap, Hilversum 199o. This book was first published in German as Religion und Religionen: Einführung in die Religionsgeschichte, Berlin 1986.

22 The closest we come to a recent general introduction to the study of religion in Dutch is Gerard Wiegers and Herman Beck's Religie in de krant: Een eerste kennismaking met de godsdienstwetenschap, Nijmegen 2005. Also, Wiegers is currently contracted to write a small book on Religie for Amsterdam University Press' series Elementaire deeltjes. The closest we have to a general introduction to the history of religion may be H.L. Beck, M. de Jonge, P.S. van Koningsveld, K. van der Toorn, T.E. Vetter, Grondleggers van het geloof: De levensverhalen van Mozes, Boeddha, Jezus en Mohammed, Amsterdam 1997. This book covers an important part of the history of religion by discussing Moses, Buddha, Jesus, and Mohammad in comparative perspective. The latest overview of the research history of the study of religion written by a Dutch scholar was Jan van Baal's Symbols for Communication, Assen 1971; 19852, with Wouter van Beek. But this excellent work is now severely outdated; even the second edition stops in 1975. It deserves mention that in 2003, Kocku von Stuckrad, who would later become professor of the study of religion in Groningen, together with Hans Kippenberg, by that time former professor of the study of religion in Groningen, published an introduction to the study of religion. See H.G. Kippenberg, K. von Stuckrad, Einführung in die Religionswissenschaft: Gegenstände und Begriffe, München 2003. Unfortunately, this book was never translated into Dutch. 
organized a PhD workshop on method and theory, we were baffled to hear from several participants that they found methodology to be an interesting 'theme', but to be not directly relevant for their own particular projects. Like their supervisors, these $\mathrm{PhD}$ students clearly considered 'method and theory' to be a field apart rather than the shared foundation of the academic study of religion. The absence of a Dutch journal dedicated exclusively to the study of religion constitutes a further institutional factor inhibiting the development of a shared disciplinary identity and a systematic research programme. In the absence of a journal dedicated exclusively to the study of religion, the NTT Journal for Theology and the Study of Religion could have assisted the development of a systematic study of religion, for example through theme issues on the formulation of a shared research agenda and on the nature of our discipline, but it has not done so. ${ }^{23}$ Finally, all appointments, except for the chairs in the comparative study of religion, are defined in terms of particular religious traditions (e.g., Hinduism, Western Christianity) or in terms of other disciplines than the study of religion (e.g., sociology of religion). Being employed as a specialist, it is little wonder if one does not prioritize contributing at the level of the discipline in general. ${ }^{24}$

\section{Why a systematic science of religion failed to develop in the Netherlands}

How could this happen? Why did a systematic science of religion fail to materialize in the Netherlands? Why did Dutch scholarship on religion collapse into particularism after leaving behind the phenomenology of religion? There are undoubtedly many causes, some structural, other personal,

23 Even in the one theme issue that did consider 'The Study of Religion Today', the contributions focused on comparative institutional history, the relation of the study of religion to other disciplines, and even the possible obsoleteness of religious studies. No space was devoted to formulating research problems and methods that could bind scholars of religion together as members of the same, systematic discipline. See B. Meyer, A.L. Molendijk (ed.), 'The Study of Religion Today', theme issue of NTT Journal for Theology and the Study of Religion 71 (2017).

24 I devote no special attention here to the unsuccessful attempt to bring into being a Netherlands Academy of Religion (NAR), because it was never the intended aim of the NAR to promote a systematic study of religion. That said, I believe that the study of religion could have benefitted from a NAR, especially as a platform through which to pursue a partnership with secondary education. 
for why things went as they did. In any case, one crucial factor was that Van Baaren himself and his closest associates in the Groningen Working-Group did not succeed in realizing their own methodological programme. In his overview of the history of the study of religion in Western Europe since the Second World War, Michael Stausberg writes: 'the grandiloquent program advanced by Van Baaren and his associates (...), especially with its ambition of explaining religious facts, has not produced the sort of scholarly output some would have hoped it would accomplish. Its main achievement remained on the programmatic level'.25 Hofstee agrees and argues that both Van Baaren's comparative work produced before the 1969/1973 piece (i.e. his dissertation on revelation, 1951) and that produced later (i.e. his book on sacrifice, 1978) was essentially phenomenological in approach. ${ }^{26}$ As Hofstee explains, Van Baaren's preoccupation with method (which he insisted should be empirical) over the equally important task of theory formation (which is necessary if one want to classify systematically and explain in any meaningful way) made his mode of comparison intuitive rather than analytical and, therefore, contrary to his own self-understanding, phenomenological. ${ }^{27}$

After Van Baaren's retirement in 1980, elements of his programme, but never the full package, were carried forward by other scholars. Van Baaren's successors in Groningen, Hans Kippenberg (1939-; prof. in Groningen till 1989) and Jan Bremmer (1944-; retired 2009), worked more historically than comparatively, but took up some of Van Baaren's explanatory ambition by integrating interpretive anthropology and Weberian and Durkheimian perspectives into their history of religion. ${ }^{28}$ Under Kippenberg, the Groningen Working-Group continued for some time - after 1983 relaunched as the

25 M. Stausberg, 'The Study of Religion(s) in Western Europe (III): Further Developments after World War II', Religion 39 (2009) 261-282, 268.

26 W. Hofstee, 'Phenomenology of Religion versus Anthropology of Religion? The Groningen School 1920-199o', in S. Hjelde (ed.), Man, Meaning, and Mystery: 100 Years of History of Religions in Norway: The Heritage of W. Brede Kristensen, Leiden 2000, 173-190, 185. 27 Hofstee, 'Phenomenology of Religion', 184-185. In his contribution to Religion, Culture and Methodology, Van Baaren's co-editor Han Drijvers emphasized the importance of theory formation, a fact later noticed by Wim Hofstee and by Armin Geertz and Russell McCutcheon. See H.J.W. Drijvers, 'Theory Formation in Science of Religion and the Study of the History of Religions', in Van Baaren, Drijvers (ed.), Religion, Culture and Methodology, 57-77; Hofstee, 'Phenomenology of Religion', 185; A.W. Geertz, R.T. McCutcheon, 'The Role of Method and Theory in the IAHR', Method \& Theory in the Study of Religion 12 (2000), 3-37, 3on78. Unfortunately, neither Drijvers himself nor any other Dutch scholar of religion that I know of went on to develop systematic methods for theory formation for our discipline. 28 Hofstee, 'Phenomenology of Religion', 186-188. 
Groningen Working Group for the Study of Religious Symbols - and from the regular seminars of this group emerged three joined publications. ${ }^{29}$ These books were, however, thematic in character, rather than truly systematic or methodological, since no attempt was made to use the individual contributions as a base for structural comparison or theory formation. After the dissolution of the working group and Kippenberg's return to Germany, especially two of the group's younger members, Wim Hofstee (1952-) and Yme Kuiper (1949-), continued to call for a systematic study of religion in their teaching and research, and in their work as board members of the Dutch Association for the Study of Religion.

Arguably, the most important contributions to a systematic study of religion in the spirit of Van Baaren were not made by members of the Groningen School, but by Jan Platvoet (1935-), who defended his dissertation in Utrecht in 1982 and became an associate professor in Leiden from 1990 until his retirement in 2000. Like Van Baaren, Platvoet envisioned two tasks for the comparative study of religion: (1) to formulate a general history of religion within the frame of a general history of human society and culture, and (2) to study the category religion and such sub-categories as religious ritual, religious experience, and religious institutions. ${ }^{30}$ What is more, Platvoet, was the Dutch scholar of religion after Van Baaren who most systematically contributed to these tasks. In his article 'History of Religion from the Neanderthal to New Age', Platvoet sketched the history of religion in terms of a cultural evolution where new forms of religion emerge as corollaries to the development of new modes of societal organisation. ${ }^{31}$ The very category of religion was scrutinized by Platvoet (and others) in what was perhaps the most successful, albeit short-lived, successor to the Groningen working-group, namely the interdisciplinary research programme 'Methods and Theories in the Study of Religions' which Platvoet ran with Arie L. Molendijk for a few years in the late 199os under the auspices of the Leiden Institute for the Study of Religions (LISOR), a research institute within the Theological

29 H.G. Kippenberg (ed.), Struggles of Gods: Papers of the Groningen Work Group for the Study of the History of Religions (Religion and Reason 31), Berlin 1984; H.G. Hubbeling, H.G. Kippenberg (ed.), On Symbolic Representation of Religion: Groninger Contributions to Theories of Symbols / Zur symbolischen Repräsentation von Religion: Groninger Abhandlungen zu verscheidenen Symboltheorien, Berlin 1986; H.G. Kippenberg, Y. Kuiper, A.F. Sanders (ed.) Concepts of Person in Religion and Thought (Religion and Reason 37), Berlin 1990.

30 J.G. Platvoet, 'Theologie als dubbelspel: Over verscheidenheid en dynamiek van theologie en godsdienstwetenschap', Nederlands Theologisch Tijdschrift 63 (2009), 221-236, 223.

31 J.G. Platvoet, 'De wraak van de "primitieven": Godsdienstgeschiedenis van Neanderthaler tot New Age', Nederlands Theologisch Tijdschrift 47 (1993), 227-243. 
Faculty of Leiden. The most important contribution from this programme was the monumental The Pragmatics of Defining Religion, in which an impressive range of Dutch and international scholars each provide their take on the issue of defining religion. ${ }^{32}$ The book would have been more effective if an effort had been made to reach a synthesis on the issue of definition and to prepare the ground for more important issues such as the question of how to formulate theory in the study of religion, but even so The Pragmatics of Defining Religion was, at least to my knowledge, one of only two books since 1973 published by a (group of) Dutch scholar(s) that aimed to tackle a fundamental methodological issue in the study of religion. The other was Platvoet's dissertation, in which he argued for the indispensability of theoretically informed comparison in the study of religion, but proposed, against Van Baaren's ambition to say general things about whole classes of religious phenomena, that one should stick to 'limitative comparison', comparing only a few carefully described cases at the time. ${ }^{33}$ Contributing further to the coherence of the discipline, Platvoet authored a series of articles on the history of the science of religion in the Netherlands. ${ }^{34}$

So there were some successful initiatives in the spirit of Van Baaren, but they were few and far between. Despite all the efforts of Platvoet, Kippenberg, Bremmer, Hofstee, and Kuiper - all of whom have now retired - a comparative and theoretically integrated study of religion never matured in the Netherlands and certainly never became discipline-defining. Some of the current chairs of comparative religion in the Netherlands publish important work on method and key terms in the study of religion, ${ }^{35}$ but none of them is involved in constructing a coherent research paradigm for a systematic science of religion. This is crucial, for within the hierarchical structure of Dutch study of religion the required impetus for change has to come from the professors, as professors hold all the positions from which change can be initiated or hindered: by custom, only professors are eligible

32 J.G. Platvoet, A.L. Molendijk (ed.), The Pragmatics of Defining Religion: Contexts, Concepts and Contests (Numen Book Series 84), Leiden 1999.

33 J.G. Platvoet, Comparing Religions: A Limitative Approach: An Analysis of Akan, ParaCreole, and Ifo-Sananda Rites and Prayers, The Hague 1982.

34 Platvoet, 'From Consonance to Autonomy'; J.G. Platvoet, 'Close Harmonies: Science of Religion in Dutch Duplex Ordo Theology, 1860-196o', Numen 44 (1998), 115-162; Platvoet, 'Theologie als dubbelspel'.

35 See, for example, R. Segal, K. von Stuckrad (ed.), Vocabulary for the Study of Religion, 3 volumes, Leiden 2015; K. von Stuckrad, 'Discursive Study of Religion: Approaches, Definitions, Implications', Method \& Theory in the Study of Religion 25 (2013), 5-25; W.J. Hanegraaff, 'Reconstructing "Religion" from the Bottom Up', Numen 63 (2016), 576-605. 
to chair the NGG, and only professors are allowed to lead the thematic NOSTER seminars which research master and doctoral students attend regularly throughout the full course of their graduate studies. ${ }^{36}$

\section{How a systematic study of religion was developed in the Nordic countries}

One needs only to look to the Nordic countries to see that the history of Dutch study of religion could have played out differently. In the Nordic countries, a comparative-systematic understanding of the study of religion similar to and contemporaneous with that of Van Baaren was formulated by scholars such as Helmer Ringgren and Åke Hultkrantz in Sweden and Lauri Honko in Finland. ${ }^{37}$ In his programmatic article 'The Phenomenology of Religion: Aims and Methods', Hultkrantz characterized Van der Leeuw's phenomenology as 'too speculative, in some places even incomprehensible' and identified Mircea Eliade's position as a form of 'religious phenomenology'. ${ }^{38}$ Against these essentialist and existentialist approaches to comparison within the study of religion Hultkrantz advocated for 'strict positive research' in the tradition of Chantepie de la Saussaye and Kristensen in the Netherlands (!) and of Geo Widengren in Sweden. His ideal phenomenology of religion was 'the systematic study of the forms of religion, [i.e. as] that part of religious research which classifies and systematically investigates religious conceptions, rites and myth-traditions from comparative morphological-typological points of view. ${ }^{39}$ It is this form of (increasingly) secular, morphological, and structural phenomenology of religion that Nordic scholars continue to nurture. Writing on the situation in Denmark today, Tim Jensen and Armin W. Geertz assert that most Danish scholars of

36 In addition, until a law change in 2017 , only full professors were entitled to act as promotors within the Dutch university system. The jus promovendus has now been extended to include also senior lecturers, but it may surprise some foreign colleagues that about half of the tenured faculty at Dutch universities - the university lecturers - remain ineligible to act as promotors.

37 H. Ringgren, Religionens form och funktion, Lund 1968; Å. Hultkrantz, 'The Phenomenology of Religion: Aims and Methods', Temenos: Studies in Comparative Religion 6 (1970), 68-88; L. Honko (ed.), Science of Religion: Studies in Methodology: Proceedings of the Study Conference of the International Association for the History of Religions, held in Turku, Finland, August 27-31, 1973 (Religion and Reason 13), Berlin 1979.

38 Hultkrantz, 'The Phenomenology of Religion', 72, 73.

39 Hultkrantz, 'The Phenomenology of Religion', 74. 
religion continue to share the conviction that 'comparative, cross-cultural studies, be they typological or genetic, are the sine qua non for the study of religions to become a science of religion in general. ${ }^{40}$

Several indicators a of 'systematic mentality' among scholars of religion in the Nordic countries confirm Jensen and Geertz' assessment. Most fundamentally, scholars of religion in the Nordic countries have a strong disciplinary identity, and their departments and study programmes are referred to as 'study of religion' in the singular (religionsvidenskab; religionsvetenskap; religionsvitenskap). More concretely, a steady stream of publications such as the following demonstrate the broadly shared interest in issues of method and theory: The Comparative Challenge in the Study of Religion, ${ }^{41}$ Charting Religion: Foundational Discussions in the Study of Religion, ${ }^{42}$ Contemporary Views on Comparative Religion, ${ }^{43}$ and Evolution, Cognition, and the History of Religion: A New Synthesis. ${ }^{44}$ Some of the most significant contributions to the development of a systematic science of religion in the Nordic countries have been made by Jeppe Sinding Jensen, whose doctoral dissertation (equivalent of a German Habilitation), The Study of Religion in a New Key: Theoretical and Philosophical Soundings in the Comparative and General Study of Religion, provides a philosophical framework for a modern comparative science of religion, and whose recent What Is Religion? is probably the best introduction to the theoretical study of religion on the market. ${ }^{45}$ It is worth pointing out that Jensen picked up most of his ideas

40 T. Jensen, A.W. Geertz, 'From the History of Religions to the Study of Religion in Denmark: An Essay on the Subject, Organizational History and Research Themes', Temenos 50 (2014), 79-113, 106. This does not, of course, mean that Danish scholars use concepts and typologies uncritically, as if these were natural givens. Indeed, as Jensen and Geertz assert, 'the Danish approach to the phenomenology of religion is not idealistic, but rather taxonomic and nominalist, in a much more theoretically grounded way than previously', ${ }_{106} n_{53}$. 41 J. Haviv, A. Lisdorf, P.W. Poulsen (ed.), Religionsvidenskabens komparative udfordring, Copenhagen 2005 .

42 T. Hammersholt, C. Schaffalitzky de Muckadell (ed.), At kortlogge religion: Grundlagsdiskussioner i religionsforskningen, Højbjerg 2011.

43 P. Antes, A.W. Geertz, M. Rothstein (ed.), Contemporary Views on Comparative Religion in Celebration of Tim Jensen's $65^{\text {th }}$ Birthday, Sheffield 2016.

44 A.K. Petersen, I.S. Gilhus, L.H. Martin, J.S. Jensen, J. Sørensen (ed.), Evolution, Cognition, and the History of Religion: A New Synthesis: Festschrift in Honour of Armin W. Geertz (Supplements to Method \& Theory in the Study of Religion 13), Leiden 2018.

45 J.S. Jensen, The Study of Religion in a New Key: Theoretical and Philosophical Soundings in the Comparative and General Study of Religion, Aarhus 2003; J.S. Jensen, What Is Religion? London $2014^{1}, 2019^{2}$. See also J.S. Jensen 'Is a Phenomenology of Religion Possible? On the Ideas of a Human and Social Science of Religion', Method \& Theory in the Study of Religion 5 (1993), 109-133. 
in the Netherlands. It was Van Baaren's work that inspired Jensen to reflect on methodology in the first place. During the 1980s, Jensen participated in the Groningen Working-Group under Kippenberg (together with his colleague Armin Geertz), and he was later involved in the LISOR programme Methods and Theories in the Study of Religions in Leiden. In an email to me, he described his entire methodological oeuvre as an attempt to philosophically ground Chantepie de la Saussaye's comparative project. ${ }^{46}$

Within the framework of a 'new comparativism', Nordic scholars of religion contributed to the study of such key categories as religious ritual, ${ }^{47}$ magic, ${ }^{48}$ asceticism, ${ }^{49}$ religious narrative, ${ }^{50}$ legitimization strategies, ${ }^{51}$ and religious experience. ${ }^{52}$ The Finn Ilkka Pyysiäinen has even proposed a new theory of religion that draws on cognitive science of religion but is still thoroughly grounded in a deep familiarity with the general history of religion. ${ }^{53}$

Nordic scholars also continue to publish solid introductions to the history of religion and to the study of religion as such, that serve the general public and are used for teaching at the secondary, vocational, and university levels. For example, some Danish core works that lack contemporary Dutch equivalents are Gyldendals religionshistorie - ritualer, mytologi, ikonografi, the primary source collection GADS religionshistoriske tekster, and the accessible and theoretically up to date Religion i psyke og samfund. ${ }^{54}$ Some

46 J.S. Jensen, personal communication 20 July 2019.

47 T. Ahlbäck (ed.), Ritualistics, Åbo 2003; J. Podemann Sørensen, 'Ritual Texts: Language and Action in Ritual', in J.P. Hoffmann (ed.), Understanding Religious Ritual: Theoretical Approaches and Innovations, London 2012, 73-92.

48 J. Sørensen, A Cognitive Theory of Magic (Cognitive Science of Religion Series), Lanham 2007 .

49 A.K. Petersen, 'A New Take on Asceticism: Asceticism as Training and Secession Suspended between Individuality and Collectivity', Numen 66 (2019), 465-498.

5o The contributions in M.A. Davidsen (ed.), Narrative and Belief: The Religious Affordance of Supernatural Fiction, London 2018.

$5^{1}$ O. Hammer, Claiming Knowledge: Strategies of Epistemology from Theosophy to the New Age (Numen Book Series 9o), Leiden 2001.

$5^{2}$ U. Schjødt, H. Stødkilde-Jørgensen, A.W. Geertz, A. Roepstorff, 'The Power of Charisma: Perceived Charisma Inhibits the Attentional and Executive Systems of Believers in Intercessory Prayer', Social Cognitive and Affective Neuroscience 4 (2011), 199-207; A. Taves, E. Asprem, 'Experience as Event: Event Cognition and the Study of (Religious) Experiences', Religion, Brain, and Behavior 7 (2017), 43-62.

53 I. Pyysiäinen, How Religion Works: Towards a New Cognitive Science of Religion, Leiden 2001.

54 T. Jensen, M. Rothstein, J. Podemann Sørensen (ed.), Gyldendals religionshistorie - ritualer, mytologi, ikonografi, Copenhagen 1994 ${ }^{1}$, 2011²; B. Alster, C. Lindtner (ed.), GADS religionshistoriske tekster, Copenhagen 1984, reprint Aarhus 2002; O. Hammer, J. Sørensen, Religion i psyke og samfund, Aarhus 2010. 
Norwegian books that I would wish we had Dutch equivalents of for teaching are Siv-Ellen Kraft and Richard Natvig's Metode ireligionsvidenskap and Ingvild Gilhus and Lisbeth Mikaelsson's critical introduction to the study of religion Hva er religion? ${ }^{55}$ The Swedes have Människor och makter 2.o: En introduktion till religionsvetenskap. ${ }^{56}$

It would take another article to argue the point in detail, but I believe that the absorption in the Nordic countries of structuralism and semiotics into the secular-typological phenomenology of religion during the $1980 \mathrm{~s}$ and 1990s was crucial for the consolidation of the comparative-theoretical project and for its ability to integrate postmodern criticisms of earlier, more naïve forms of comparativism. ${ }^{57} \mathrm{I}$ also think that it was the fruitful fusion of typological phenomenology and structuralism, especially in Denmark and Finland, that laid the groundwork for the Nordic countries (and especially the Section for the Study of Religion in Aarhus), to become a world-leading centre for theoretical study of religion. ${ }^{58}$ It has also been of paramount importance that the Nordic countries are home to no less than five peer-reviewed journals dedicated to the study of religion: Temenos: Nordic Journal for Comparative Religion, founded in 1965 and published by the Finnish Society for the Study of Religion; Chaos: Skandinavisk tidsskrift for religionshistoriske studier, founded in 1982 and published by the sections for the study of religion in Copenhagen, Odense, Bergen, and Lund;

55 S.-E. Kraft, R.J. Natvig (ed.), Metode i religionsvitenskap, Oslo 20o6; I.S. Gilhus, L. Mikaelsson, Hva er Religion?, Oslo 2007.

56 S. Arvidsson, J. Svensson (ed.) Människor och makter 2.o: En introduktion till religionsvetenskap, Halmstad $2008^{1}, 2010^{2}$.

57 Compare J.S. Jensen, 'Meaning and Religion: On Semantics in the Study of Religion', in P. Antes, A.W. Geertz, R.R. Warne (ed.), New Approaches to the Study of Religion, Volume 1. Regional, Critical, and Historical Approaches, Berlin 2004, 219-252; Stausberg, 'The Study of Religion(s)', 269; Jensen, Geertz, 'From the History of Religions', 91-93.

$5^{8}$ Michael Stausberg agrees with this assessment and remarks: 'The recent rise of cognitive approaches (especially in the US, the UK, Denmark, and Finland) may owe its special appeal to the promise of rehabilitating a scientifically grounded comparative and cross-cultural agenda'; 'The Study of Religion(s)', 269n52. For further details on the recent research history of the study of religion in Denmark, see A.W. Geertz, T. Jensen (ed.), Religionsforskningen før og nu [The Study of Religion Past and Present], Vol. II, Nyere tid. Copenhagen 2015. See, in particular, the three chapters in the section on Komparation, Tim Jensen and Jørgen Podemann Sørensen's 'Nyere religionsfænomenologi', Hans J. Lundager Jensen's 'Strukturalisme', and Arun Micheelsens 'Religionssemiotikken'. No similar anthology outlines the newer research history of Dutch study of religion. A briefer overview of the history of the study of religion in Denmark is provided in Jensen, Geertz, 'From the History of Religions'; for Norway, one may consult I.S. Gilhus, K.A. Jacobsen, 'From the History of Religions to the Science of Religion in Norway', Temenos: Nordic Journal for Comparative Religion 5o (2014), 63-78. 
Religionsvidenskabeligt Tidsskrift, also founded in 1982 and published by the Section for the Study of Religion in Aarhus; Din: Tidsskrift for religion og kultur, founded in 2009 and edited by scholars of religion from Bergen; and Approaching Religion, founded in 2011 and published by the Donner Institute for Research in Religious and Cultural History in Åbo, Finland.59 Temenos, Religionsvidenskabeligt Tidsskrift, Dīn, and Approaching Religion (but not Chaos) are published open access, and together, the five journals facilitate discipline-wide discussions and help maintain cohesion within the study of religion as a whole. This is achieved, in particular, by the frequent publication of theme issues based on seminars and conferences. For example, the latest theme issue of Chaos treated 'Ritualer og ritualstudier'; the last four issues of Religionsvidenskabeligt Tidsskrift were all theme issues and dealt, in turn, with processions, the discipline's (half)-forgotten heroes, reforms and reformations, and the relation between impurity and salvation. ${ }^{60}$

It is only fair to point out that favourable institutional circumstances contributed significantly to the Nordic success, even if some of those favourable circumstances were created by Nordic scholars of religion themselves. In the Nordic countries independent departments and study programmes in the study of religion (formerly history of religion) have existed for more than hundred years, and as a result most current faculty members have themselves been trained in the study (or history) of religion.

59 In addition to the five academic journals, there are also journals run by students. In Denmark, each department for the study of religion has its own student-run journal that publishes book reviews and articles based on papers and theses. Staff members also contribute to the journals as authors and advisors to the student editors. Tabu (f. 1987) is based in Copenhagen, TOTEM (f. 1998) is based in Aarhus, and Axis Mundi (f. 2018) is based in Odense.

6o It may not be a coincidence that this shift in academic centrality from the Netherlands to the Nordic countries (and especially Denmark) was mirrored by a shift in administrative centrality. The International Association for the History of Religions (IAHR, initially the International Association for the Study of the History of Religions; IASHR) was founded in 1950 during an international conference in Amsterdam. C. Jouco Bleeker served as the first general secretary of the IAHR/IASHR between $195^{\circ}$ and 1970, and as editor-in-chief of NUMEN from 1960 to 1975. During this time, the Netherlands was recognized as one of the absolute heartlands of the discipline. Between 1995 and 2015, the post of general secretary of the IAHR was in Danish hands, with Armin W. Geertz serving from 1995 to 2005, and Tim Jensen serving from 2005 to 2015 (and currently serving as president); before this Jensen had served as the first general secretary of the European Association for the Study of Religions 2000-2004. The current European editor of the journal NUMEN (Laura Feldt) is based at the University of Southern Denmark, and the current European editor of the journal Religion (Michael Stausberg) is based in Bergen, Norway. 
By contrast, at my own department in Leiden, I am the only faculty member who was formally trained in the study of religion, whereas my colleagues, including those who today self-identify as scholars of religion, were trained in such disciplines as theology, history, psychology, law, and Arabic and Persian philology. Equally important is the fact that the study of religion in the Nordic countries has gradually taken over (from theology) the responsibility for educating upper secondary school teachers for the school subject Religion. ${ }^{61}$ In Denmark, historians of religion have been involved, together with theologians, in educating upper secondary school teachers since 1912 within the study programme 'Christian Studies', but in the beginning Christian Studies was dominated by theologians and it was only after generations of struggle that the study of religion gained the upper hand. A significant contribution was made by Arild Hvidtfeld, who in 1961 became the first Danish historian of religion to publish a secondary school textbook, an example followed by his students, and by their students in turn. ${ }^{62}$ It was not until 1996, however, that candidates with a full degree in the Study of Religion (rather than in Christian Studies) became entitled to teach religion in upper secondary schools, and soon after Christian Studies was abolished. ${ }^{63}$ Since the mid-199os the partnership with secondary education has allowed the sections for the study of religion in the Nordic countries to grow considerably and to maintain more institutional independence than their Dutch counterparts. Increasingly, the study of religion is also expanding into primary education, either by educating those teacher trainers who educate primary school teachers in religion (Denmark) or by educating primary school teachers directly (Finland, Norway, and Sweden).

Why does all this matter? Why is it a problem that Dutch scholars of religion are particularists who do not aim to collectively build and nurture a comparative and theoretical 'science of religion' in the way that this is done in the Nordic countries? It matters because without a shared disciplinary identity as scholars of religion we are extra vulnerable to budget cuts and institutional restructurings. It matters because as long as we lack commitment to a systematic research programme on religion in general, we can provide no raison d'être for the maintenance of independent study

61 On the intimate relation between the study of religion and religion education in the Nordic countries, see W. Alberts, T. Jensen (ed.), 'Religious Education in the Nordic Countries', theme issue of Temenos: Nordic Journal for Comparative Religion 49 (2013).

62 See Jensen, Geertz, 'From the History of Religions', 81, 83

63 On religion education in Denmark, see also T. Jensen, 'The Study of Religions and Religion in Denmark', Nederlands Theologisch Tijdschrift 61 (2007), 329-342. 
programmes and departments, nor do we have anything of our own to offer academics from other disciplines. Without lay introductions to the study of religion we cannot showcase the contributions of our discipline to politicians and prospective students. The Nordic countries provide an interesting mirror for us. It would be too easy to say that the study of religion in the Nordic countries has been successful simply because there happened to be a better job market (as teachers) for those graduated in the study of religion in those countries. The fact is that it was the tireless effort of generations of scholars of religion that made the fortunate cooperation with (secondary) education possible. What is more, a shared disciplinary identity, a commitment to the comparative and theoretical study of religion, the development of a research infrastructure (esp. journals), and a strong dedication to writing for a general audience preceded the successful joint venture with the secondary schools - made it possible even. The Nordic countries thus provide us with a constructive example: we are not victims of fate or context. We can take matters in our own hands and change things, even if the change is bound to come slowly.

\section{A way out of the crisis: A systematic science of religion à la Van Baaren}

It is now urgent to raise the question how we can find a way out of the current crisis. Now is the right time to act - not only because doing nothing will certainly result in further dismantling of our discipline, but also because institutional developments out of our control offer us a window of opportunity. Van Baaren and his associates and successors had to make room for themselves within faculties of theology that were rather unwelcoming to secular and systematic study of religion, even at the state universities of Groningen and Leiden. Now that several universities have given up theology (Leiden, Amsterdam, Utrecht) while theology itself is increasingly resembling the study of religion in terms of methodology and outlook, an important obstacle for the development of a systematic study of religion seems to be out of the way. We need to act quickly, however, before we find ourselves again in a situation where a stronger discipline (area studies and anthropology, in their postmodern theory-hostile incarnations) will be able to quagmire us. Perhaps it is already too late. I hope that it is not. What I suggest is that we reorient our discipline in a four-fold way that essentially amounts to realizing Van Baaren's original project: a systematic study of religion aimed at analytical theorizing. Just as Van Baaren found inspiration 
for his project in cultural anthropology, we too may seek inspiration for this endeavour in other disciplines that value comparison and theory-building in the study of culture, such as linguistics, narratology, and sociology.

First, all us of working at sections for the study of religion need to re-establish the clear focus on religion as our common object of study that Van Baaren and the phenomenologists shared, and hence to commit to a disciplinary identity as scholars of religion. This entails adopting a 'realist ontology' of religion that takes the concept 'religion' to refer to real structures and subject matters in the world, in opposition to the anti-realist or constructionist position that claims that 'religion' exists only in the mind of scholars, and that there are no 'religions'. As Kevin Schilbrack has convincingly shown the 'anti-realist' alternative is philosophically untenable and methodologically undesirable because it directs our attention to the way the term 'religion' (and equivalent terms) are used, whereas our real concern should be with those real-world structures to which the term refers. ${ }^{64}$ Of course, our discipline would be even more effective and coherent if we could agree on a definition of religion, preferable a substantive definition that avoids any assumptions about the function of religion. For example, we might stipulate religion to be all those beliefs, practices, experiences, narratives, and discourses that assume the existence of transempirical agents, worlds, and/or processes. ${ }^{65}$

64 K. Schilbrack, 'Religions: Are There Any?' Journal for the American Academy of Religion 78 (2010), 1112-1138; K. Schilbrack, 'A Realist Social Ontology of Religion', Religion 47 (2017), 161-178. This is not to say that the structures and subject matters that the term 'religion' refers to are 'essentially' religious prior to our categorization of them as such. By contrast, on the realist view defended by Schilbrack and endorsed here, definitions are always stipulative that is, they do nothing else but identify a chunk of reality - stuff that existed prior to the crafting of our definition - as the conventional referent of a particular concept (in our case 'religion') in a particular context (say, in the context of a particular research programme). 65 Like Van Baaren's circumscription, this definition identifies the assumed existence of transempirical beings and powers as the essential element that sets religion apart from non-religion. At the same time, it avoids two pitfalls in Van Baaren's conceptualization. First, it avoids Van Baaren's intellectual reductionism. By defining religion as 'a complex of notions', Van Baaren effectively places the practices that such notions may prompt or be sustained by (as well as many other things) outside religion proper (compare Clifford Geertz' reduction of religion to a 'system of symbols'). A better definition allows for various 'ontological loci' of religion, including beliefs (or notions, ideas), as well as practices, experiences, narratives, and discourses. Second, the definition proposed here avoids Van Baaren's restriction of the notion of 'religion' to institutionalized religion (which he sets against 'religiosity') and to the religion of the majority within a given culture or sub-culture (which he sets against 'superstition'); 'Science of Religion', 40. 
Second, we need from Van Baaren (and the phenomenologists) the ambition to compare. According to Van Baaren, comparison means looking for patterns in the large corpus of data collected by anthropologists and historians of religion, with the aim of categorizing the material systematically. We should certainly engage in such 'taxonomic comparison', but commitment to comparison entails other aims as well. Even historical and ethnographic studies that aim primarily to understand some individual case should, if they are to be relevant to the general study of religion, themselves already involve an aspect of 'illuminative comparison', i.e. comparison of the case in point with other similar cases. ${ }^{66}$ Furthermore, comparison becomes scientifically meaningful only if it helps us solve theoretically informed research problems. As Ivan Strenski puts it: Only if we make general problems the focus of our attention may the study of religion achieve the coherence of a discipline. ${ }^{67}$ Strenski usefully distinguishes between categorial problems, about the category religion itself (e.g., 'what is religion?'; 'how many religions are there?') and 'infracategorial' (or comparative) problems. Infracategorial problems, I add, can guide comparative work of various sorts. They can aim for generalisations (e.g., do religions with a human founder tend to deify him/her?), for the construction of taxonomies (e.g., in which principal ways do religions with human founders relate to these after their death?), and for the illumination of single cases (e.g., how come that religion $\mathrm{X}$ with a human founder did not deify him, given that deification of human founders is the general norm?) ${ }^{68}$

Third, and as implied by Van Baaren, comparison and explanation should go together. After having established certain patterns in the material by means of comparative analysis (e.g., religions with a human founder do tend to deify him, unless...) we can move on to ask why these patterns arise,

66 I borrow the terms taxonomic and illuminative comparison from Oliver Freiberger. See O. Freiberger, 'Elements of a Comparative Methodology in the Study of Religion', Religions 9 (2018), art. 38; O. Freiberger, Considering Comparison: A Method for Religious Studies, Oxford 2019. Arvind Sharma has made the case for a form of illuminative comparison in which two traditions (or methods) shed light on each other; he refers to this method as 'reciprocal comparison'. See A. Sharma, Religious Studies and Comparative Methodology: The Case for Reciprocal Illumination, Albany 2005.

67 I. Strenski, 'Why It Is Better to Know Some of the Questions Than All of the Answers', Method \& Theory in the Study of Religion 15 (2003), 169-186.

68 On these three main forms of comparative work, see also D.M. Freidenreich, 'Comparisons Compared: A Methodological Survey of Comparisons of Religion from "A Magic Dwells" to A Magic Still Dwells', Method \& Theory in the Study of Religion 16 (2004), 8o-101. 
and to pose the equally crucial question why certain cases do not conform to the general pattern. ${ }^{69}$ In raising these explanatory questions, we should draw - critically - on the best analytical theories from the humanities, social sciences, and cognitive sciences. The aim of our systematic study of religion should be to explain how various aspects of religion work (e.g., how cognitive biases constrain religious morality), how various building-blocks of religious traditions play together (e.g., under which circumstances rituals and narratives reinforce belief), and which historical patterns can be discerned in the development of individual religious traditions and in the development of religion as such over the full course of human evolution. Crucially, none of this can be achieved without comparison, i.e. without drawing on material from many different religions, areas, and periods. In addition, comparison is needed to challenge Western-centric theorizing gone wild, for example when theories with universal ambitions turn out to be based exclusively on samples from WEIRD societies (Western, Educated, Industrialized, Rich, Democratic) whose particular cognition and action modes are confounded with those of the human species as such. ${ }^{70}$

Furthermore, in order to theorize effectively, we need - and this is my fourth point - to spell out the full implications of the principle of methodological agnosticism. On the epistemological level, the principle of methodological agnosticism points to the fact that religious postulations are transempirical - they are both unverifiable and unfalsifiable. This is beyond discussion. What we need to realize - in addition to this - is that the methodological agnostic, whenever he or she moves from description to explanation, has to choose sides (as a scholar, methodologically) between two ontological models of reality - methodological naturalism and methodological supernaturalism. As scholars of religion we all study people who postulate the existence of gods and spirits, and who explain all kinds of phenomena as resulting from the actions of these transempirical beings (e.g., a dream is a vision; a recovery results from answered prayers). As Lauri Honko formulated it in his study of sauna spirits and other spirits among the Ingrians in Northwestern Russia: 'Das psychologische Grundproblem ist somit folgendes: wie ist es möglich, dass ein Mensch etwas sieht, hört oder fühlt, was objektiv betrachtet nicht vorhanden ist?'71 In tackling this problem

69 Compare Freidenreich, 'Comparisons Compared'.

70 J. Henrich, S.J. Heine, A. Norenzayan, 'The Weirdest People in the World?' Behavioral and Brain Sciences 33 (2010), 61-135.

71 L. Honko, Geisterglaube in Ingermanland, Erster Teil (FF Communications 185), Helsinki 1962, 94 . 
we must choose between two positions: either we side with religion's own self-understanding and assume the religionist position of methodological supernaturalism (=the actual presence of spirits in the sauna give rise to the experience), or we consider religion a work of the human imagination and adopt the position of methodological naturalism or non-supernaturalism (=there are no spirits in the sauna, but personal convictions and social expectations steer the interpretation of ambiguous sensory input, such as shadows and unusual sounds, towards the conclusion that there are spirits in the sauna). To Honko, and to the scholar of religion in general, only the position of methodological naturalism is theoretically productive. In general terms: when taken to its logical consequence, the principle of methodological agnosticism (as an epistemological principle) necessarily entails methodological naturalism (as an ontological principle). ${ }^{72}$

\section{Conclusion, or, where to begin}

To conclude, the phenomenology of religion - while certainly also marred by such flaws as religionism, essentialism, and use of unreliable ethnographic data - possessed one crucial virtue worth maintaining: the ambition to study and theorize religion in comparative perspective. Van Baaren and the Groningen Working-Group recognized this and tried to salvage the comparative and explanatory ambition of the old paradigm, even to the extent that they made comparativism a cornerstone of their methodological programme for a systematic science of religion. Unfortunately, Van Baaren, his associates (especially Han Drijvers), and later scholars inspired by him (chief among them Jan Platvoet), were unable to develop a systematic science of religion in the Netherlands. Without a common object (religion)

72 On the issue of methodological naturalism, see also the contributions in J.N. Blum (ed.), The Question of Methodological Naturalism (Supplements to Method \& Theory in the Study of Religion 11), Leiden 2018. Craig Martin agrees with me that methodological naturalism is unavoidable unless we embrace supernaturalism or 'disingenuously obscure the particular ontology at work in our descriptions'; 'Incapacitating Scholarship: Or, Why Methodological Agnosticism Is Impossible', 53-73, 71. Other contributors formulate a defence for methodological agnosticism against methodological naturalism. For a more detailed discussion of what I consider the fundamental principles of sound study of religion, see M.A. Davidsen, 'The Spiritual Tolkien Milieu: A Study of Fiction-based Religion', doctoral dissertation, Leiden 2014, 30-38, on the relation between methodological agnosticism and methodological naturalism in particular, 32n4o, https://openaccess.leidenuniv.nl/handle/1887/29078, accessed 26 August 2019 . 
and a shared agenda of comparative research problems, Dutch study of religion has fallen into an academic crisis where scholars of religion even deny the existence of their own discipline. What is more, our lack of disciplinary self-consciousness has left us defenceless against institutional restructurings and budget cuts, and has aggravated, for our discipline, the already devastating effects of the neo-liberal assault on the humanities. Since 2000, several Dutch universities have demoted faculties of theology or the study of religion to institutes within faculties of humanities, or even to sub-institute capacity groups or centres. ${ }^{73}$ We have also witnessed the discontinuation of independent degree programmes in the study of religion (both BA and MA) at Tilburg University. More universities may choose to discontinue study programmes or disband departments for the study of religion in the near future. The direness of the situation is presented in full detail in the 2015-rapport from the Royal Netherlands Academy of Arts and Sciences (KNAW), Klaar om te wenden... ${ }^{74}$

The study of religion has been largely emancipated from theology, but we now risk coming under the yoke of area studies and anthropology. In the past, theology tolerated particularistic studies of various non-Christian religions but opposed the systematic study of religion. This is no longer the case, for over the last thirty years theology has increasing 'de-theologized' into a 'science of religion of Christianity'.75 Today's threat comes from area studies and anthropology where postmodernist, postcolonialist, and feminist critiques have spawned an opposition towards the comparative, theoretical, and systematic study of religion. This situation leaves us with a choice. Either we stay particularistic and allow ourselves to be slowly swallowed by other disciplines. Or we regroup and consolidate ourselves as scholars of religion with a shared disciplinary identity and a shared research agenda. I believe that the study of religion in the Netherlands can only survive, let alone thrive, if we choose the path of the systematic study of religion. We need to respond to postmodern criticism not by giving up theorizing, but by improving our theorizing. Only by doing so and by

73 For an overview of the drastic changes in the 200os, which include the demotion of the Faculties of Theology in Amsterdam (in 2002) and in Utrecht (in 2005) and of the Faculty for the Sciences of Religion in Leiden (in 2009), see Platvoet, 'Theologie als dubbelspel', 225-226. Since 2009, the main institutional change has been the further demotion of the Leiden Institute for Religious Studies (LIRS) into the Leiden University Centre for the Study of Religion within the Leiden Institute for Area Studies in 2015.

74 Koninklijke Nederlandse Akademie van Wetenschappen, Klaar om te wenden... De academische bestudering van religie in Nederland: een verkenning, Amsterdam 2015.

75 Platvoet, 'Theologie als dubbelspel', 224-227. 
adopting an explanatory perspective that allows for the absorption of new theoretical paradigms, including the cognitive science of religion, can we reinvigorate our discipline and demonstrate its relevance for the other humanistic and social-scientific disciplines.

It would be naïve to think that a change of mentality from 'particularism' to 'systematism' will be enough to save our discipline. Institutional initiatives are needed as well. Good places to start would be to form a new working-group for the study of fundamental problems and methods in the study of religion within the NGG or NOSTER, and to use the NTT Journal for Theology and the Study of Religion as a platform for discussing the future of our discipline (or, alternatively, launch a new journal focused narrowly on the comparative and theoretical study of religion). Perhaps we could publish an anthology on fundamental problems in the study of religion to mark the 75 years anniversary of the NGG in 2022 or the 5 o years anniversary of Van Baaren's pivotal article in 2023. A more ambitious plan would be to develop a big research programme, aimed to consolidate a systematic science of religion in the Netherlands, for example within the Zwaartekracht (Gravity) scheme of the Dutch Research Council (NWO). We also need to (re)introduce courses into our teaching programmes that can form our students as systematic scholars of religion. Four core courses strike me as particularly necessary: (1) a course on the general history of religion, preferably from a cultural evolutionary perspective; $(2)$ a course on comparative categories such as ritual, myth, and mysticism aimed to teach students the basic vocabulary of the comparative study of religion and to categorize and analyse primary source material from the history of religion; (3) a course on the research history of the study of religion that pays due attention to developments in the Netherlands; and (4) (at the master level) an interdisciplinary theory and methods course that can offer students the tools they need to analyse and explain religion. ${ }^{76}$ All staff employed at departments for the study of religion should be willing and able to teach such courses. We also need to encourage our students to develop some philological

76 With the curriculum revision in 2015 we introduced three of these four core courses into our degree programmes in Leiden, none of which has a counterpart anywhere else in the Netherlands. In the Bachelor programme, Professor of Comparative Study of Religion Ab de Jong teaches the course Religion in the World which presents the history of religion through the lens of cultural evolution, as well as the course Onderzoeksgeschiedenis (Research History). In the Master, I myself teach the course Tools and Theories in the Study of Religion that aims to introduce students to those cognitive, social-scientific, and literary theories can could (and should) be integrated in a future, truly systematic study of religion. We still need a course on 'religious categories' but hope to develop such as a course in the near future. 
competence. ${ }^{77}$ Another necessary initiative will be to develop a close alliance between the study of religion and secondary religion education like in the Nordic countries. To this end a working-group on 'The Study of Religion and Education' within the NGG was founded in 2018, and scholars of religion have been involved in establishing the Expert Centre for Worldview and Religion Education (Expertisecentrum Levensbeschouwing en Religie in het Voortgezet Onderwijs), also launched in 2018. ${ }^{78}$ Impetus can only be kept, however, if more colleagues become involved.

As a final point, let me suggest that we revive another part of Van Baaren's heritage. Van Baaren considered writing for the general public at least as important as writing for fellow specialists because he was convinced that 'through more and better knowledge about the plurality of religious cultures the world might become a place with less social inequality, armed conflicts and daily racism. ${ }^{79}$ This is a noble aim and one we should share. But writing for the general public is also a way of showcasing the importance of the knowledge produced by our discipline for politicians, teachers, prospective students (and their parents), potential employers of our alumni, and academics in other disciplines. Many Dutch scholars

77 On the point of language competency, comparison with the Nordic countries is again illuminating. In Denmark, students are required to spend at least 30 European Credit Transfer and Accumulation System points (ECs) on language acquisition (traditionally either Koine Greek, Latin, Classical Arabic, Hebrew, Sanskrit, Pali, or Old Norse, but today more choice is allowed) and an additional ${ }_{15}$ ECs on a paper that makes use of the acquired philological competency. Because this philological competency is demanded by the secondary schools (!), Danish BA study programmes in the study of religion are extended by 30 ECs to a total of 210 ECs.

78 The homepage of the expert centre can be visited here: https://expertisecentrumlervo. $\mathrm{nl} /$, accessed 31 January 2020. The current initiatives to form an alliance between the study of religion and religion education build on and profit from earlier discussions within the NGG; see G. Wiegers, A.F. de Jong (ed.), 'Godsdienstwetenschap in het middelbaar onderwijs', theme issue of Nederlands Theologisch Tijdschrift 61 (2007). Elsewhere, I have presented some ideas on how to develop Dutch secondary education in direction of the Nordic model. See M.A. Davidsen, 'Het begrip religie: Over het religiewetenschappelijke definitiedebat en zijn implicaties voor het voortgezet onderwijs', Narthex: Tijdschrift voor levensbeschouwing en educatie 18 (2018), 58-64; M.A. Davidsen, 'Objectief, kritisch en pluralistisch? Wat Nederland kan leren van het Noorse onderwijs over levensbeschouwing en religie', Narthex: Tijdschrift voor levensbeschouwing en educatie 19 (2019), 11-19; M.A. Davidsen, 'Religiewetenschappelijke vakdidactiek', in M. van Dijk-Groeneboer (ed.), Handboek Vakdidactiek Levensbeschouwing en Religie, 202O, https://expertisecentrumlervo.nl/wp-content/uploads/2020/o2/Digitaleversie-Handboek-Vakdidactiek-Levensbeschouwing-Religie.pdf, accessed 4 juni 2020.

79 W. Hofstee, 'Making Knowledge Public: Theo van Baaren as a Broker of Religious and Artistic Knowledge', paper read at the annual conference of the European Association for the Study of Religion (EASR) / University of Groningen, The Netherlands, May 11-15, 2014. 
already write excellent books for the general public about their own specializations. What I am calling for here are popularizing books about (the study and history of) religion in general.

\section{Acknowledgments}

This article is based on a paper presented at the third Tri-university Colloquium (co-operation between the departments for the study of religion at Leiden, Utrecht, and Amsterdam) on 'The Science of Religion at the Post-theological University', held on 14 June 2019 in Leiden. The author wants to express his gratitude to Wim Hofstee and Jan Platvoet for invaluable comments on earlier versions of the text, and to Jeppe Sinding Jensen and Tim Jensen for help with various details. Conversations with $\mathrm{Ab}$ de Jong, Gerard Wiegers, and Michael Stausberg helped improve the argument significantly.

\section{About the author}

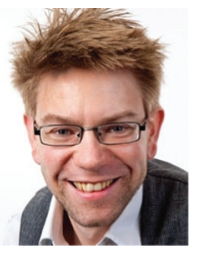

Markus Altena Davidsen (1981) is University Lecturer in the Sociology of Religion at the Leiden University Centre for the Study of Religion, Matthias de Vrieshof 1, $2311 \mathrm{BZ}$ Leiden, The Netherlands.

Areas of Expertise: Fiction-based Religions, Pragmatics of Religious Narratives, Method and Theory in the Study of Religion, Religion and Education.

E-mail:m.davidsen@hum.leidenuniv.nl 
